\title{
Effect of surface modification of silicone on Staphylococcus epidermidis adhesion and colonization
}

\author{
Haiying Tang, ${ }^{1}$ Ting Cao, ${ }^{1}$ Anfeng Wang, ${ }^{1}$ Xuemei Liang, ${ }^{1}$ Steven O. Salley, ${ }^{1}$ James P. McAllister II, ${ }^{2}$ \\ K. Y. Simon $\mathbf{N g}^{\mathbf{1}}$ \\ ${ }^{1}$ Department of Chemical Engineering and Materials Science, Wayne State University, \\ 5050 Anthony Wayne Drive, Detroit, Michigan 48202 \\ ${ }^{2}$ Department of Pediatric Neurosurgery, Children's Hospital of Michigan, Wayne State University, \\ 4201 Antoine Street, UHC-6E, Detroit, Michigan 48201
}

Received 4 January 2006; revised 26 May 2006; accepted 9 June 2006

Published online 27 October 2006 in Wiley InterScience (www.interscience.wiley.com). DOI: 10.1002/jbm.a.30952

\begin{abstract}
Cerebrospinal fluid (CSF) shunts for the treatment of hydrocephalus are generally made of silicone rubber. The growth of bacterial colonies on the silicone surface leads to frequent CSF shunt complications. A systematic study of the effect of the surface modification of silicone on Staphylococcus epidermidis adhesion and colonization was performed for different incubation times by means of colony counting and scanning electron microscopy (SEM). Silicone was modified with different biopolymers and silanes, including heparin, hyaluronan, octadecyltrichlorosilane (OTS), and fluoroalkylsilane (FAS) to provide a stable and biocompatible surface with different surface functional groups and degrees of hydrophobicity. The modified silicone surfaces were studied by using contact angle measurements, X-ray photoelectron spectroscopy (XPS), and atomic force microscopy (AFM). After 4 and
\end{abstract}

$8 \mathrm{~h}$ of incubation, the FAS- and OTS-coated silicone and the hyaluronan coated OTS/silicone surfaces showed significantly reduced bacterial adhesion and colonization compared to blank silicone by both quantification methods. However, the heparin coated OTS/silicone showed significantly increased bacterial adhesion. These results indicate that the nature of the surface functional group and surface roughness determine the extent of bacterial adhesion and colonization. However, the degree of hydrophobicity of the surface did not appear to play a determining role in bacterial adhesion and colonization. (c) 2006 Wiley Periodicals, Inc. J Biomed Mater Res 80A: 885-894, 2007

Key words: bacterial adhesion; colonization; modified silicone; Staphylococcus epidermidis

\section{INTRODUCTION}

Recent statistics from the US Center for Disease Control and Prevention indicate that hydrocephalus affects about one out of every 1,000 births. Hydrocephalus is a lifelong condition since the patient is treated with cerebrospinal fluid (CSF) "shunt" catheters rather than "cured". However, complications with CSF shunts often occur. Approximately $70 \%$ of shunts fail within 10 years of placement, and $85 \%$ of shunt-dependent patients have had at least two shunt revisions. ${ }^{1,2}$ Recently, the overall cost for shunt treatment was estimated at $\$ 1$ billion per year in the United States. ${ }^{3}$ Among CSF shunt complications, tissue obstruction $(31.4 \%)$ and infection $(8.1 \%)$ are the two most common causes. ${ }^{4}$ The reported frequency

Correspondence to: K.Y.S. Ng; e-mail: sng@wayne.edu Contract grant sponsor: Wayne State University of infected shunt varies from 2 to $31 \%$ with an average of $10-15 \% .^{5-9}$ Infants under 6 months have a higher incidence of infection (15-25\%) than older children and adults $(3-5 \%) .{ }^{10}$ Most shunt infections occur within 30 weeks after surgery; $71 \%$ appeared within 4 months of shunt placement, and $90 \%$ occur within 6 months. ${ }^{11,12}$ Shunt infections are generally believed to be due to microscopic contamination at the time of implantation, caused by isolated microorganisms ${ }^{6,13}$ which are derived mainly from the patient's skin flora. Over $40 \%$ of shunt infections are caused by Staphylococcus epidermidis (S. epidermidis) ${ }^{14,15}$ which is one of the most common coagulase negative staphylococci isolated from medical device infections. The bacterium is an opportunistic pathogen and produces an extracellular slime that binds well to shunt surfaces and leads to shunt infection. ${ }^{16}$ Also it has been shown in an in vivo study that infection is more likely with a greater inoculum of bacteria. ${ }^{17}$ Thus, reducing the number and colonization of bacteria that adhere to shunts should reduce the risk of infection. 
Despite the advancement of modern neurosurgical techniques and prophylactic use of antibiotics, bacterial infections still result in shunt blockage and malfunction. With regards to the mechanism of shunt infection, the silicone elastomer in shunts seems to enhance the virulence of microorganisms. ${ }^{18-20}$ Previous studies have demonstrated that an antimicrobial-impregnated shunt reduced the incidence of CSF shunt infection. ${ }^{21-26}$ In our earlier study, rifampicin cast molded silicone inhibited the growth of bacterial adhesion significantly. ${ }^{27}$ Modification of material surfaces with various biocompatible polymers has been frequently attempted in order to decrease bacterial adhesion. Heparin ${ }^{28,29}$ has been claimed to reduce bacterial attachment, and hyaluronan coated on poly(ethyleneterephthalate) (PET) by a photoimmobilization method has been reported to reduce platelet adhesion and thrombus formation. ${ }^{30}$ Alkyl- and fluoroalkyl-substituted silanes have been used to form smooth, stable, and reproducible silane films of monolayer thicknesses. ${ }^{31,32}$ The self-assembled monolayer (SAM) produced a hydrophobic surface ${ }^{33,34}$ and the longer fluorocarbon chain was associated with reduced bacterial adhesion. ${ }^{35,36}$ There are many factors that have been thought to influence bacterial adherence to biomaterial surface, including the chemical composition of the material, surface hydrophobicity, surface roughness, and surface charge. ${ }^{37}$ However, the specific characteristics of a surface have not been fully elucidated and conflicting results have been reported. For example, a hydrophilic surface has been reported to reduce bacterial adhesion while bacteria adhered strongly to the most hydrophobic materials. ${ }^{38,39}$ On the other hand, Price et al. ${ }^{35}$ suggested that hydrophobicity was not a significant factor.

The objective of this study was to systematically evaluate the effect of the surface modification of silicone rubber on bacterial adhesion and colonization. Octadecyltrichlorosilane (OTS, $\mathrm{CH}_{3}\left(\mathrm{CH}_{2}\right)_{17} \mathrm{SiCl}$,) and trichloro $\left(1 \mathrm{H}, 1 \mathrm{H}, 2 \mathrm{H}, 2 \mathrm{H}\right.$-perfluoroctyl)silane (FAS, $\mathrm{CF}_{3}$ $\left.\left(\mathrm{CF}_{2}\right)_{5}\left(\mathrm{CH}_{2}\right)_{2} \mathrm{SiCl}_{3}\right)$, which have long lengths of alkyland fluroalkyl-silane molecules, were coated on silicone to provide different degrees of hydrophobicity. Heparin and hyaluronan were used to change the hydrophobic silicone surface to hydrophilic. Heparin and hyaluronan were coated on silicone using a photoimmobilization method because previous studies have demonstrated that photoimmobilized heparin on silicon shows superior stability. ${ }^{40}$

\section{MATERIALS AND METHODS}

\section{Microorganism}

The S. epidermidis strain ATCC 35984 was obtained from ATCC (American Type Culture Collection, Manassas, VA).
It was isolated from a catheter sepsis case. S. epidermidis were streaked and grown on tryptic soy agar (TSA, Difco Laboratories, Detroit, MI) from a frozen stock. The plate was then maintained at $4^{\circ} \mathrm{C}$ for no longer than 2 weeks. The culture was grown in $30 \mathrm{mg} / \mathrm{mL}$ tryptic soy broth (TSB, Difco Laboratories, Detroit, MI) to mid log phase at $37^{\circ} \mathrm{C}$ at a $300 \mathrm{rpm}$ shaker speed. The optical density at $600 \mathrm{~nm}$ was measured, and the bacterial concentration was adjusted to $1.0 \times 10^{8} \mathrm{CFU} / \mathrm{mL}\left(\mathrm{OD}_{600}=0.20\right)$ in TSB.

\section{Materials}

Silastic silicone sheets (thickness, $0.4 \mathrm{~mm}$ ) were obtained from Specialty Manufacturing (Saginaw, MI) and were cut into uniform $21 \mathrm{~mm}$ diameter disks. Octadecyltrichlorosilane (97.5\%) was purchased from United Chemical Technologies (Bristol, PA). Heparin, hyaluronan, trichloro $(1 H, 1 H, 2 H$, $2 \mathrm{H}$-perfluoroctyl)silane (97\%), 1-3-Dimethylaminoprppyl-3ethylcarbodiimide hydrochloride (98\% water-soluble carbodiimide, WSC), 4-azidoanilinehydrochloride $(97 \%)$, glutaraldehyde (50 wt \%), and phosphate-buffered saline (PBS: $\mathrm{NaCl}$ : $0.138 M, \mathrm{KCl}: 0.0027 \mathrm{M}$; $\mathrm{pH}$ 7.4) were obtained from Sigma-Aldrich (St. Louis, MO). Ethyl alcohol (200 Proof, absolute, dehydrated) was purchased from Pharmco Products Inc. (Brookfield, CT). Sodium chloride $(\mathrm{NaCl})$ was obtained from Fisher Scientific (Pittsburgh, PA). All chemicals were used without further purification.

\section{Coating}

\section{Surface modification of silicone with OTS}

The silastic disks were cleaned by immersion in anhydrous ethyl alcohol in an ultrasonic cleaner (Branson 2200, Danbury, CT) for $5 \mathrm{~min}$, and dried with nitrogen. The samples were then treated by oxygen plasma cleaner (PDC-3XG, Harrick Scientific Corporation, Ossining, NY) for $5 \mathrm{~min}$ at high level. Subsequently, the oxygen plasma-treated silicone samples were placed with only one surface exposed together with a glass cup filled with $1 \mathrm{~mL}$ OTS into a sealed chamber $(3 \mathrm{~L})$ at $10^{-3}$ Torr and at room temperature for $4 \mathrm{~h}$. The samples remained in the sealed chamber with OTS at $10^{-2}$ Torr for an additional $12 \mathrm{~h}$. Only the exposed surface was modified with an OTS SAM layer.

Photoimmobilization of heparin and hyaluronan on OTS modified silicone

Heparin, WSC, and 4-azidoanilinehydrochloride at a weight ratio of 2.35:1.29:1 were dissolved in deionized water (DI water) to make a $0.5 \%$ solution. The $\mathrm{pH}$ of the solution was adjusted to $4.70-4.75$ using $2.3 \mathrm{~N} \mathrm{NaOH}$ and $0.1 \mathrm{~N} \mathrm{NaOH}$ solutions at room temperature, and then stirred at $4{ }^{\circ} \mathrm{C}$ for $24 \mathrm{~h}$. A $0.2 \%$ aryl azido-modified hyaluronan solution was prepared by the same method except that the weight ratio was 2.16:1.64:1. All of the reactions were carried out in a dark room. The OTS on silicone samples were illuminated with a mercury vapor UV lamp (175 Watts, Regent Lighting, Burlington, NC) for $10 \mathrm{~min}$ at a 
distance of $10 \mathrm{~cm}$ in the presence of the aryl azido-modified heparin or hyaluronan solution. The samples were then rinsed with DI water for $48 \mathrm{~h}$.

\section{Surface modification of silicone with FAS}

The silastic disks were cleaned by immersion in anhydrous ethyl alcohol in an ultrasonic cleaner for $5 \mathrm{~min}$, and dried with nitrogen. The samples were then treated by oxygen plasma cleaner for $5 \mathrm{~min}$ at high level, and then FAS was deposited on the silicone surface by chemical vapor deposition for $5 \mathrm{~min}$ at room temperature under a vacuum of $10^{-3}$ Torr. The samples were then maintained in the sealed chamber with FAS at 0.3 Torr for an additional $4 \mathrm{~h}$.

\section{Characterization}

In vitro stability tests and contact angle measurements

In order to determine the stability of the coatings, OTS/ silicone, FAS/silicone, heparin/OTS/silicone, and hyaluronan/OTS/silicone samples were each placed in $5 \mathrm{~mL}$ of $0.9 \% \mathrm{NaCl}$ solution at $37^{\circ} \mathrm{C}$ for various periods of time. After 5, 10, 20, and 30 days, the samples were retrieved and rinsed with DI water copiously. Contact angles of the samples were then measured using a Rame-hart NRL contact angle goniometer (Model 100, Landing, NJ) in the laboratory atmosphere. A water droplet of approximately $20 \mu \mathrm{L}$ was placed on the substrate surface and the contact angles were measured on both sides of the droplet. Three droplets were placed at various spots on the substrate surface and the average readings were reported.

\section{X-ray photoelectron spectroscopy}

XPS analysis of the samples prior to incubation experiments was performed with a PHI 5500 system (Perkin Elmer, Wellesley, MA), using a monochromatic aluminum $\mathrm{K} \alpha \mathrm{X}$-ray radiation source $(1486.6 \mathrm{eV})$ and AugerScan system control (RBD Enterprises, Bend, OR). The base pressure of the system was between $2-4 \times 10^{-10}$ Torr. All measurements were conducted at a $45^{\circ}$ take-off angle and the voltage and current of the anode were $15 \mathrm{kV}$ and $13.5 \mathrm{~mA}$, respectively. The pass energies for survey and multiplex scans were 117.4 and $23.5 \mathrm{eV}$, respectively. Element concentration on the sample surface was measured by XPS multiplex scan (spot size: $\sim 1 \mathrm{~mm}$ diameter).

\section{Atomic force microscopy}

All surface roughness measurements of samples before incubation experiments were acquired with a Digital Instruments Nanoscope IV controller and Dimension 3100 scanning probe microscope scanner (Veeco Instrument, Santa Barbara, CA). Height images $\left(10 \times 10 \mu \mathrm{m}^{2}\right.$ scan area) of samples were taken in ambient air using ultrasharp silicon NSG 10 cantilevers (NT-MDT, Moscow, Russia) with a resonance frequency of about $300 \mathrm{kHz}$. Tapping mode was used and the scan rate was $0.5 \mathrm{~Hz}$. The radius of the tip was specified to be about $10 \mathrm{~nm}$. Root-mean-square (RMS) roughness was obtained over the entire image area.

\section{Adhesion assay}

The adhesion of bacteria to surfaces was evaluated by the following means. Three disks of each untreated and modified silicone were sterilized in $70 \%$ ethyl alcohol for $5 \mathrm{~min}$ and then placed with the modified surface upwards in a sterile, 12-well flat-bottomed tissue culture plate (Corning Incorporated, Corning, NY). The samples were secured on the bottom using Teflon O-rings (Zatkoff Seals \& Packings, Farmington Hills, MI). Three $\mathrm{mL}$ of bacteria suspension $\left(1.0 \times 10^{8} \mathrm{CFU} / \mathrm{mL}\right)$ were added to each well. Samples were then incubated at $37^{\circ} \mathrm{C}$ at a $150 \mathrm{rpm}$ shaker speed for 4 and $12 \mathrm{~h}$. After the incubation period, samples were washed three times in $15 \mathrm{~mL} 0.01 \mathrm{M}$ PBS to remove nonadherent bacteria. The samples were then placed in $10 \mathrm{~mL}$ of PBS in $50 \mathrm{~mL}$ sterile centrifuge tubes (Corning Incorporated Corning, NY), and were sonicated (Branson $1510 \mathrm{R}-$ $\mathrm{MT}, 70 \mathrm{~W}, 42 \mathrm{KHz}$, Danbury, CT) for $10 \mathrm{~min}$. This ultrasonication process was repeated four times with fresh PBS, to ensure complete detachment of all adherent bacteria. The sonicated solutions for each sample were combined in a centrifuge tube and diluted to 1:10, 1:100, and 1:1,000. Each of these diluents $(0.05 \mathrm{~mL})$ was spread over the surface of a TSA plate using an inoculating turntable (Fisher Scientific). These plates were then incubated at $37^{\circ} \mathrm{C}$ for $24 \mathrm{~h}$, and the number of colonies was counted.

\section{Scanning electron microscopy}

After incubation with the bacterial culture for 4, 12, and $24 \mathrm{~h}$, samples were rinsed three times in $15 \mathrm{~mL} 0.01 \mathrm{M}$ PBS to remove nonadherent bacteria, and fixed with glutaraldehyde solution $(2.5 \%$ in $0.01 \mathrm{M}$ PBS) for $1 \mathrm{~h}$. The samples were then sequentially dehydrated for $10 \mathrm{~min}$ in 50, 70, 90, and $96 \%$ ethyl alcohol solutions, and then with absolute alcohol for $20 \mathrm{~min}$. Samples were gold coated using a sputter coater (Ernest F. Fullam Incorporated, Latham, NY) at $50 \mathrm{~mA}$ for $25 \mathrm{~s}$. A Hitachi S-2400 scanning electron microscope operated at $20 \mathrm{kV}$ was used to examine the samples at a magnification of $2000 \times$. SEM images were obtained at nine equally spaced, nonoverlapping locations on the sample surface. SEM images were visually evaluated to semiquantify the extent of bacterial adhesion and colonization on the surfaces. A ranking scheme, which is similar to that of Cagavi et al. ${ }^{7}$ was adopted:

- Grade 1: Size of colony $\sim 2 \mu \mathrm{m}$

- Grade 2: Size of colony $\sim 5 \mu \mathrm{m}$

- Grade 3: Size of colony $\sim 10 \mu \mathrm{m}$

- Grade 4: Size of colony $\sim 20 \mu \mathrm{m}$

- Grade 5: Size of colony $\sim 40 \mu \mathrm{m}$

\section{Statistical tests}

For each sample, three sets of contact angle data and bacterial adhesion counts were obtained and analyzed statisti- 
TABLE I

Contact Angle Measurements of Modified Silicone Surfaces as a Function of Exposure Times to Saline Solution at $37^{\circ} \mathrm{C}$

\begin{tabular}{|c|c|c|c|c|}
\hline & \multicolumn{4}{|c|}{ Contact Angle $\left({ }^{\circ}\right)$} \\
\hline & OTS/silicone & FAS/silicone & $\begin{array}{l}\text { Heparin/OTS/ } \\
\text { silicone }\end{array}$ & $\begin{array}{c}\text { Hyaluronan/OTS/ } \\
\text { silicone }\end{array}$ \\
\hline Control & $102.3 \pm 1.4$ & $112.2 \pm 2.6$ & $55.3 \pm 1.8$ & $55.3 \pm 3.9$ \\
\hline 5 days & $101.7 \pm 3.1$ & $113.2 \pm 1.6$ & $58.2 \pm 4.2$ & $54.7 \pm 1.6$ \\
\hline 10 days & $100.0 \pm 2.8$ & $112.2 \pm 1.5$ & $57.0 \pm 4.0$ & $54.4 \pm 2.8$ \\
\hline 20 days & $102.3 \pm 1.9$ & $110.0 \pm 2.0$ & $53.3 \pm 2.2$ & $56.7 \pm 2.2$ \\
\hline 30 days & $102 \pm 2.8$ & $112.8 \pm 1.7$ & $55.2 \pm 3.2$ & $54.5 \pm 2.9$ \\
\hline$p$-value & 0.455 & 0.068 & 0.124 & 0.609 \\
\hline
\end{tabular}

Coated surfaces were found to be stable for a period of 30 days. Contact angle measurement of uncoated silicone was $107.4 \pm 1.3$. The p-values were higher than 0.05, suggesting the difference of contact angles measured at different time was not significant statistically.

cally with a one-way analysis of variance (ANOVA) using MINITAB 13 (Minitab). A subsequent student's $t$-test was performed to evaluate individual differences, with $p<0.05$.

\section{RESULTS}

\section{Stability test and contact angle measurements}

The contact angle for untreated silicone was found to be $107.4^{\circ} \pm 1.3^{\circ}$. After treatment with oxygen plasma for $5 \mathrm{~min}$, the surface was fully oxidized, and the contact angle reduced to $0^{\circ}$. Upon coating with OTS and FAS, the contact angle increased to over $100^{\circ}$, resulting in hydrophobic surfaces. However, when heparin and hyaluronan were coated on OTS/silicone, the surface became hydrophilic with a contact angle of $55.3^{\circ}$ (Table I).

To determine the stability of the coatings in saline solution, the contacted angle for the coated silicone surfaces were measured as a function of time (Table I). These results indicate that the outermost surface coated with OTS, FAS, heparin, and hyaluronan are stable for up to 30 days.

\section{Surface roughness}

Figure 1 shows characteristic AFM images of silicone, FAS/silicone, OTS/silicone, hyaluronan/OTS/ silicone, and heparin/OTS/silicone. The uncoated silicone surface exhibited a rough surface [Fig. 1(a)] and a high RMS value. The surfaces are much smoother upon coating [Fig. 1(b-e)]. The surface roughness of FAS/silicone, OTS/silicone, and hyaluronan/OTS/ silicone samples were also significantly reduced. However, there was no statistical difference between heparin/OTS/silicone and uncoated silicone.

\section{XPS analysis}

Table II shows the surface elemental composition of silicone, OTS/silicone, FAS/silicone, heparin/ OTS/silicone, and hyaluronan/OTS/silicone as control and after 5 days in saline solution at $37^{\circ} \mathrm{C}$. For the OTS/silicone, the $\mathrm{C} \%, \mathrm{O} \%$, and $\mathrm{Si} \%$ were 50.4 , 24.8 , and $24.8 \%$, respectively. After 5 days in saline solution, the $\mathrm{C} \%, \mathrm{O} \%$ and $\mathrm{Si} \%$ were essentially unchanged at $48.3,29.7$, and $22.0 \%$, respectively. With the addition of the heparin layer, $\mathrm{C} \%, \mathrm{O} \%, \mathrm{Si} \%$, and $\mathrm{N} \%$ were 50.8, 25.2, 20.4, and 3.6\%, respectively. $\mathrm{N}$ was observed as new element on the heparin/OTS/ silicone indicating that the heparin was successfully coated onto OTS/silicone. After 5 days in saline solution, $\mathrm{C} \%, \mathrm{O} \%, \mathrm{Si} \%$, and $\mathrm{N} \%$ were almost unchanged at 50, 24.6, 21.9, and 3.5\%, respectively. Similarly, for the hyaluronan/OTS/silicone, C\%, $\mathrm{O} \%, \mathrm{Si} \%$, and $\mathrm{N} \%$ were $49.2,26.3,20.9$, and $3.6 \%$, respectively. The increase in $\mathrm{N} \%$ indicates that hyaluronan is coated on OTS/silicone. After 5 days in saline solution, $N \%$ remained at $3.5 \%$. For the FAS/ silicone, $\mathrm{C} \%, \mathrm{O} \%, \mathrm{Si} \%$, and $\mathrm{F} \%$ were 24.3, 21.5, 13, and $41.2 \%$, respectively, with the increase in $\mathrm{F} \%$ indicating that FAS was coated on silicone. After 5 days in saline solution, $\mathrm{F} \%$ was maintained at around $41 \%$. On the basis of these results, the OTS/ silicone, FAS/silicone, and heparin/OTS/silicone, appear to be very stable for up to 5 days.

\section{SEM images of bacterial adhesion and colonization}

Figure 2 shows a series of representative scanning electron microscope images of $S$. epidermidis after 4 , 12, and $24 \mathrm{~h}$ incubation on silicone [Fig. 2(a-c)], FAS/silicon [Fig. 2(d-f)], OTS/silicone [Fig. 2(g-i)], hyaluronan/OTS/silicone [Fig. 2(j-1)], and heparin/ OTS/silicone [Fig. 2(m-o)]. For each sample, nine SEM images were obtained. Individual cells and/or 

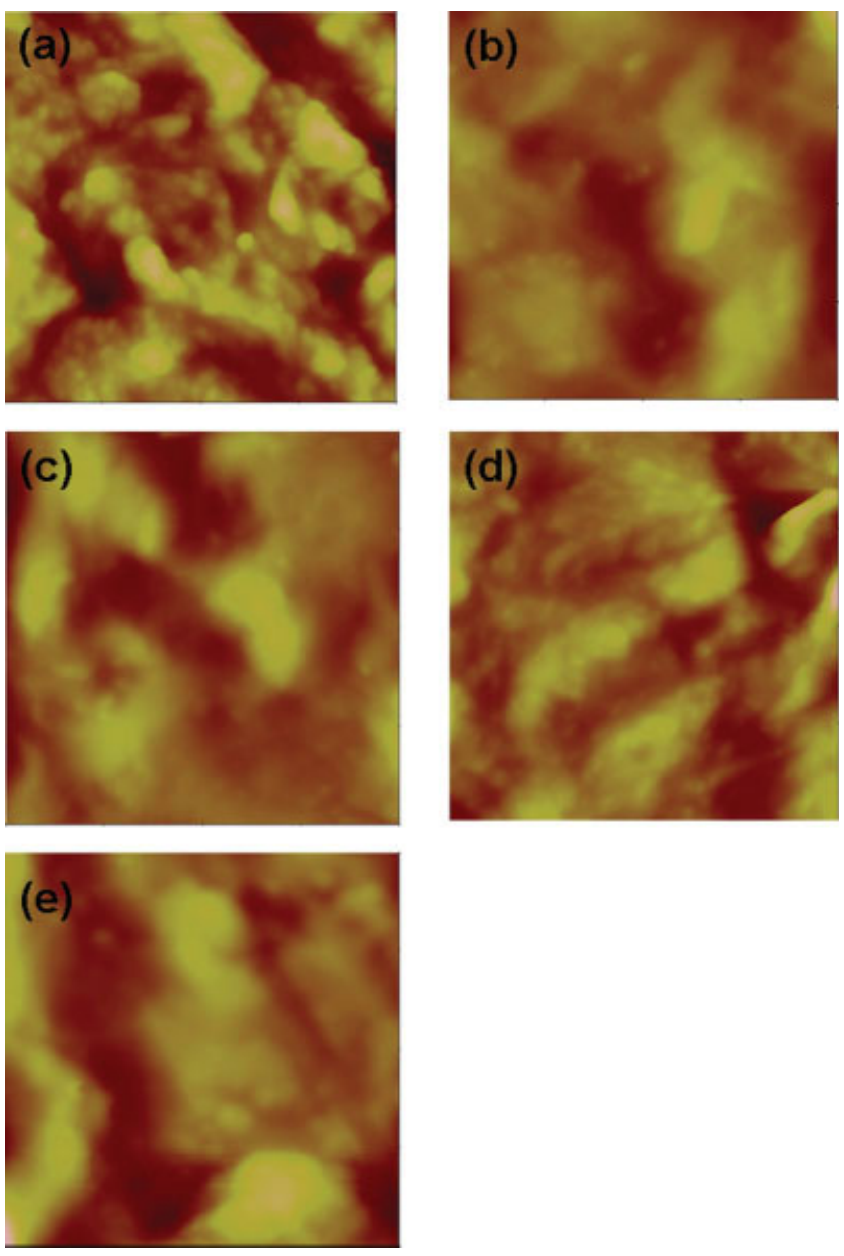

Figure 1. AFM images of (a) silicone, (b) FAS/silicone, (c) OTS/silicone, (d) hyaluronan/OTS/silicone, and (e) heparin/ OTS/silicone. The scan area is $10 \times 10 \mu \mathrm{m}^{2}$. The corresponding mean RMS values are $153.9 \pm 46.2 \mathrm{~nm}, 88.8 \pm 12.5 \mathrm{~nm}^{*}, 81.1 \pm$ $26.4 \mathrm{~nm}^{*}, 96.8 \pm 18.3 \mathrm{~nm}^{*}$, and $104.1 \pm 20.7 \mathrm{~nm}$, respectively. "*" indicates significant difference compared to untreated silicone $(p<0.05)$. [Color figure can be viewed in the online issue, which is available at www.interscience.wiley.com.]

clusters were observed on most of the images. Individual cells were about $0.5-0.8 \mu \mathrm{m}$ in diameter, which agrees well with reported values. ${ }^{41}$
After $4 \mathrm{~h}$ of incubation, numerous $10 \mu \mathrm{m}$ and $20 \mu \mathrm{m}$ colonies were observed on the silicone surface [Fig. 2(a)]. On the other hand, eight $5 \mu \mathrm{m}$ and two $10 \mu \mathrm{m}$ colonies were observed on FAS/silicone [Fig. 2(d)], nine $5 \mu \mathrm{m}$, five $10 \mu \mathrm{m}$, and one $20 \mu \mathrm{m}$ colonies were observed on OTS/silicone [Fig. 2(g)] and eleven $5 \mu \mathrm{m}$ and three $10 \mu \mathrm{m}$ colonies were found on hyaluronan/OTS/silicone [Fig. 2(j)]. Moreover, numerous colonies $(\sim 10, \sim 20$, and $\sim 40 \mu \mathrm{m})$ were found on heparin/OTS/silicone [Fig. 2(m)]. The results indicate that bacterial adhesion and colonization are highest on heparin/OTS/silicone and are lowest on FAS/silicone at $4 \mathrm{~h}$.

After $12 \mathrm{~h}$ of incubation, a significant increase in the number and size of colonies was observed on both silicone [Fig. 2(b)] and heparin/OTS/silicone [Fig. 2(n)]. However, twelve $5 \mu \mathrm{m}$ and ten $10 \mu \mathrm{m}$ colonies were found on FAS/silicone [Fig. 2(e)]; twenty-seven $5 \mu \mathrm{m}$, thirteen $10 \mu \mathrm{m}$, and two $40 \mu \mathrm{m}$ colonies were observed on OTS/silicone [Fig. 2(h)]; and four $5 \mu \mathrm{m}$, seven $10 \mu \mathrm{m}$, and one $40 \mu \mathrm{m}$ colonies were seen on hyaluronan/OTS/silicone [Fig. 2(k)]. It should be noted that the trend of bacteria adhesion and colonization on different surfaces was the same at 4 and $12 \mathrm{~h}$ incubation.

After $24 \mathrm{~h}$ of incubation, large colonies of $\sim 20$ and $\sim 40 \mu \mathrm{m}$ were observed on both silicone [Fig. 2(c)] and heparin/OTS/silicone [Fig. 2(o)], respectively. However, the numbers and colony sizes decreased at $24 \mathrm{~h}$ compared to $12 \mathrm{~h}$. On the other hand, one colony of $20 \mu \mathrm{m}$ was found on FAS/silicone [Fig. 2(f)] and five $20 \mu \mathrm{m}$ colonies were seen on OTS/silicone [Fig. 2(i)]. For hyaluronan/OTS/silicone [Fig. 2(1)], one $20 \mu \mathrm{m}$ and two $40 \mu \mathrm{m}$ colonies were observed.

\section{Semiquantitative analysis using SEM images}

Table III summarizes the results of bacterial adhesion and colonization using the ranking system on different samples after 4,12 , and $24 \mathrm{~h}$ incubation. For example, at 4 h, 50 grade 3, 20 grade 4,4 grade

TABLE II

Surface Chemical Composition of Silicone and Coated Silicone Samples in Saline for 0 and 5 Days, Obtained from XPS Multiplex Scans

\begin{tabular}{|c|c|c|c|c|c|c|c|c|c|c|}
\hline \multirow[b]{3}{*}{ Sample } & \multicolumn{10}{|c|}{ Elemental Composition (\%) } \\
\hline & \multicolumn{2}{|c|}{$\mathrm{C}$} & \multicolumn{2}{|c|}{$\mathrm{O}$} & \multicolumn{2}{|c|}{$\mathrm{Si}$} & \multicolumn{2}{|c|}{$\mathrm{N}$} & \multicolumn{2}{|c|}{$\mathrm{F}$} \\
\hline & Control & 5 days & Control & 5 days & Control & 5 days & Control & 5 days & Control & 5 days \\
\hline Silicone & 47.6 & & 26.9 & & 25.5 & & & & & \\
\hline OTS/silicone & 50.4 & 48.3 & 24.8 & 29.7 & 24.8 & 22 & & & & \\
\hline Heparin/OTS/silicone & 50.8 & 50 & 25.2 & 24.6 & 20.4 & 21.9 & 3.6 & 3.5 & & \\
\hline Hyaluronan/OTS/silicone & 49.2 & 49.5 & 26.3 & 26.3 & 20.9 & 20.7 & 3.6 & 3.5 & & \\
\hline FAS/silicone & 24.3 & 25.7 & 21.5 & 20.2 & 13 & 12.7 & & & 41.2 & 41.5 \\
\hline
\end{tabular}



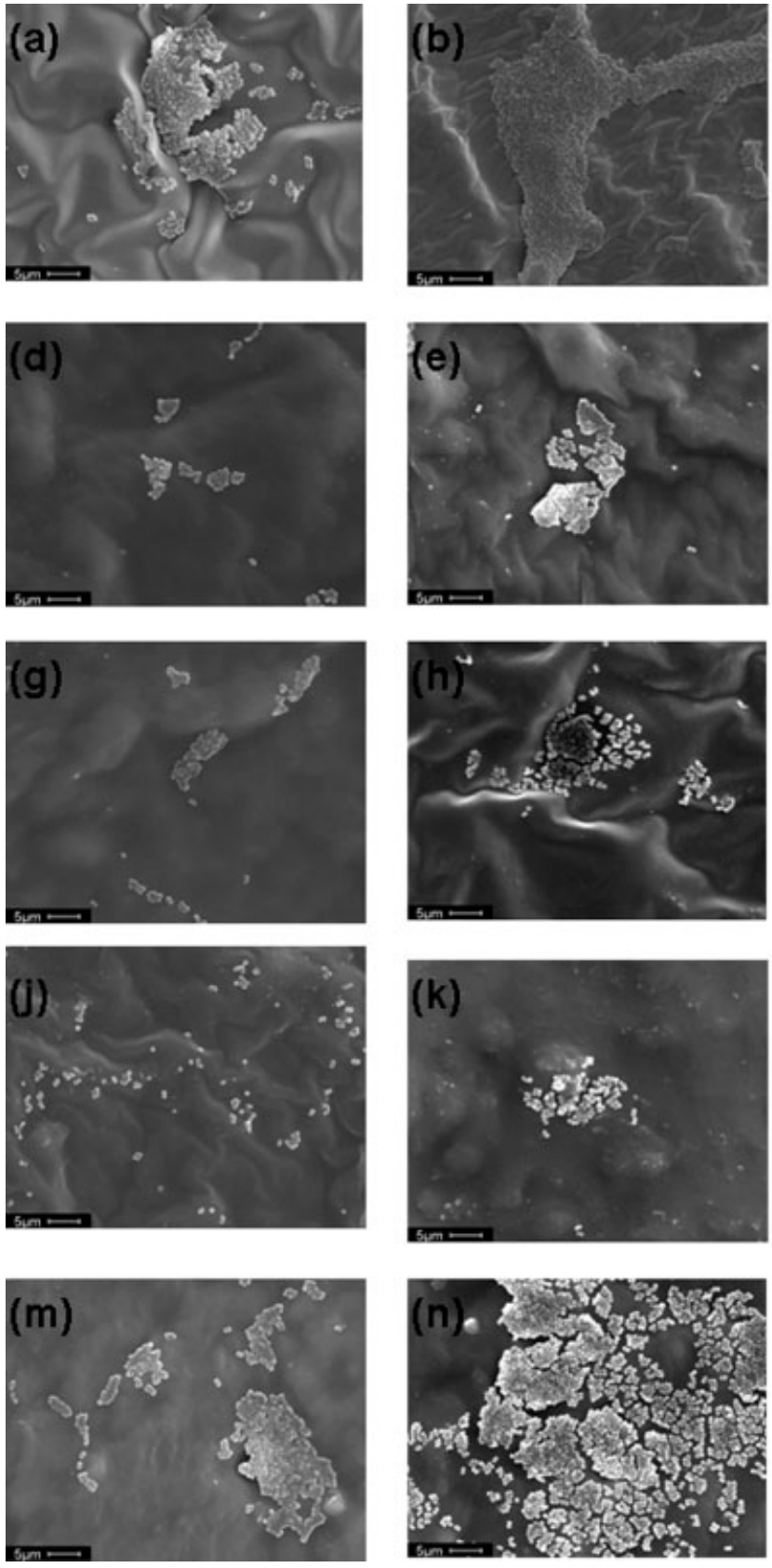
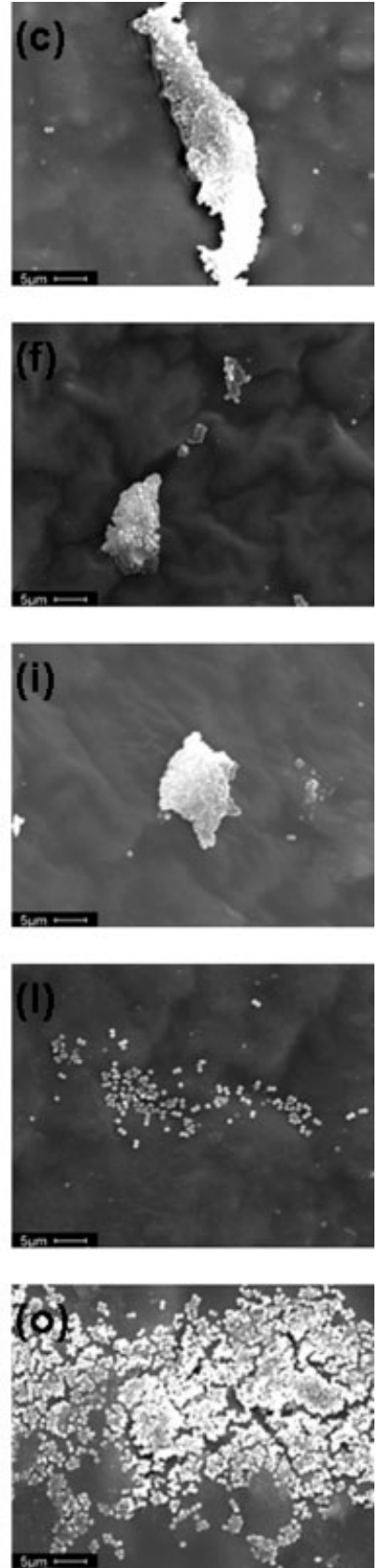

Figure 2. SEM images of S. epidermidis on modified silicone surface after 4, 12, and $24 \mathrm{~h}$ incubation: (a)-(c) silicone; (d)(f) FAS/silicone; (g)-(i) OTS/Silicone; (j)-(l) hyaluronan/OTS/silicone; (m)-(o) heparin/OTS/Silicone. Scale bar is $5 \mu \mathrm{m}$.

5, and numerous grades 1 and 2 were observed on heparin/OTS/silicone, leading to a mean grading of grade 4 . On the other hand, 10 grade 1,8 grade 2, and 2 grade 3 colonies was observed on FAS/silicone resulting in a mean grading of grade 2 . Table IV shows the mean ranking of different surfaces at different incubation times. The lowest bacterial adhesion and colonization was observed on FAS/silicone, while the highest was noted on heparin/OTS/silicone at 4, 12, and $24 \mathrm{~h}$. However, at $24 \mathrm{~h}$, the mean ranking, as compared to $12 \mathrm{~h}$, was decreased for silicone and heparin/OTS/silicone surfaces; while the mean ranking of OTS/silicone, FAS/silicone, and hyaluronan/OTS/silicone surfaces was unchanged.

\section{Adhesion assay results}

Figure 3 shows the quantity of $S$. epidermidis adhered on different surfaces as a function of incubation time as measured by colony counts. For 4 and $8 \mathrm{~h}$, the pattern of bacterial adhesion on the five different surfaces was found to be FAS/silicone $<$ OTS/silicone $<$ hyaluronan/OTS/silicone $<$ silicone $<$ hepa- 


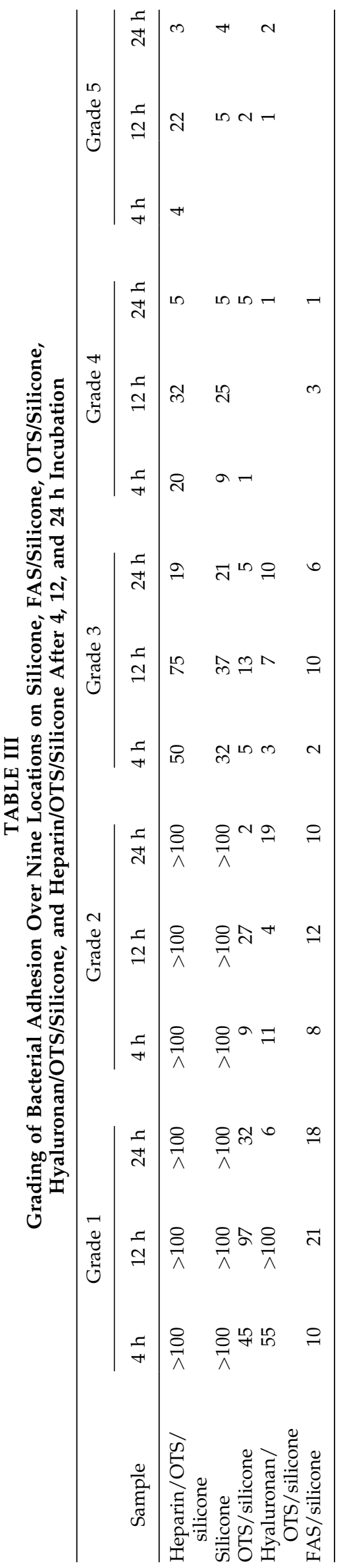

rin/OTS/silicone. For $12 \mathrm{~h}$, the pattern was somewhat different with hyaluronan/OTS/silicone having the fewest bacteria.

\section{DISCUSSION}

Silicone rubber has been the primary material used in shunt systems for the treatment of hydrocephalus for almost fifty years. Silicone has many desirable properties: it is highly flexible, nontoxic, and with low surface energy and good thermal and chemical stability. However, silicone is a foreign material, thus is more prone to infection than normal body tissue. Bacterial adhesion and colonization on the silicone surface leads to frequent CSF shunt complications. In the present study, we modified the silicone surface so that different degrees of hydrophobicity, surface roughness, and surface functional groups were obtained. The contact angle measurements and XPS results at each preparative stage demonstrated that the coatings were present and those silanes and polymer coatings were very stable over a 30-day period.

On the basis of SEM images and colony counting, FAS/silicone was found to inhibit bacterial adhesion and colonization. This result agrees with a similar study on fluoro-alkylsiloxane layers with different fluorocarbon chains chemisorbed on silicone rubber. ${ }^{36}$ Blank silicone has functional groups $\left(\mathrm{Si}-\mathrm{CH}_{3}\right.$ and $\mathrm{Si}-\mathrm{O}-\mathrm{Si}$ ) protruding from its surface, while FAS/silicone has a relatively large fluorinated carbon-chain $\left[\mathrm{CF}_{3}\left(\mathrm{CF}_{2}\right)_{5}\left(\mathrm{CH}_{2}\right)_{2}\right]$, which possibly may be a factor in reducing bacterial adhesion. This finding also supports the general belief that the long chain, lower surface energy of stable functional groups can inhibit bacterial adhesion. ${ }^{35}$ Similarly, OTS/silicone with an alkyl chain of 17 methylene units $\left[\mathrm{CH}_{3}\left(\mathrm{CH}_{2}\right)_{17}\right]$ was found to reduce the bacterial adhesion and colonization. However, bacterial adhesion on FAS/silicone was $50 \%$ less than that of OTS/silicone, which can be attributable to the nature of terminal group $\left(-\mathrm{CF}_{3}\right)$ on the FAS/silicone com-

TABLE IV

Mean Ranking of Bacterial Adhesion on Silicone, FAS/ Silicone, OTS/Silicone, Hyaluronan/OTS/Silicone, and Heparin/OTS/Silicone After 4, 12, and $24 \mathrm{~h}$ Incubation

\begin{tabular}{lccc}
\hline \multicolumn{1}{c}{ Sample } & $4 \mathrm{~h}$ & $12 \mathrm{~h}$ & $24 \mathrm{~h}$ \\
\hline $\begin{array}{l}\text { Heparin/OTS/ } \\
\text { silicone }\end{array}$ & Grade 4 & Grade 5 & Grade 4 \\
$\begin{array}{l}\text { Silicone } \\
\begin{array}{l}\text { OTS/silicone } \\
\text { Hyaluronan/OTS/ } \\
\text { silicone }\end{array}\end{array}$ & Grade 3 & Grade 4 & Grade 4 \\
FAS/silicone & Grade 2 & Grade 3 & Grade 3 \\
\hline
\end{tabular}




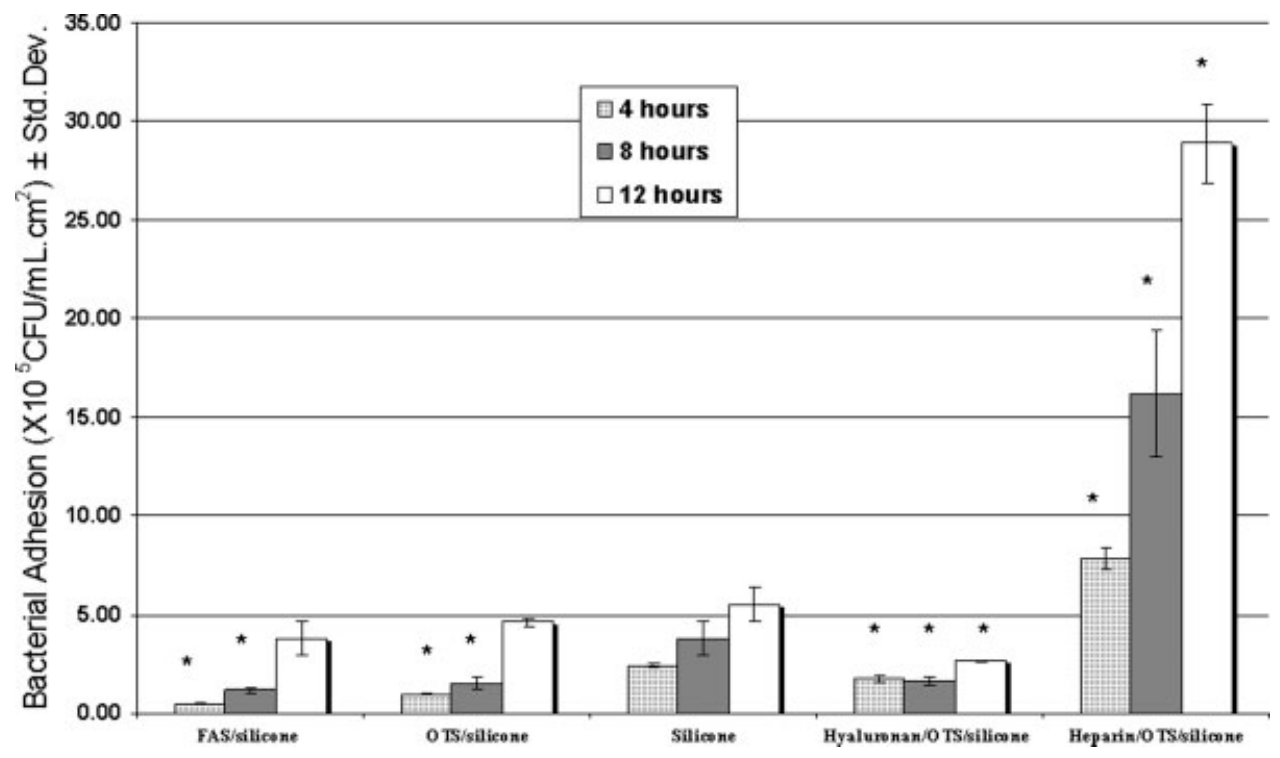

Figure 3. S. epidermidis adherence on silicone, FAS/silicone, OTS/silicone, hylauronan/OTS/silicone, and heparin/OTS/ silicone for 4,8 , and $12 \mathrm{~h}$ incubation as measured by plate counting. Three sets of experiments were conducted and data presented were the mean counts of bacteria \pm standard deviation. "** indicates significant difference compared to untreated silicone $(p<0.05)$.

pared to the terminal group $\left(-\mathrm{CH}_{3}\right)$ on OTS/silicone.

Comparing the extent of bacterial adhesion and colonization reduction on hyaluronan/OTS/silicone to silicone, it was found that bacterial adhesion on hyaluronan/OTS/silicone surfaces after $4 \mathrm{~h}$ incubation was about two times lower than at 8 and $12 \mathrm{~h}$. This suggests that overall bacteria counts are the result of two processes: initial adhesion and subsequent colonization. In this case, the hyaluronan coating may have reduced initial irreversible adhesion by $28 \%$ as compared to silicone. However, after 8 and $12 \mathrm{~h}$ of incubation, the bacterial count was much lower compared to the other surfaces. Thus, the overall bacterial count approached that of OTS/silicone at $8 \mathrm{~h}$; and finally exhibited the lowest bacterial count at $12 \mathrm{~h}$. This suggests that the hyaluronan surface is not conducive to bacterial growth. A previous study also reported that hyaluronic acid inhibited the adhesion of S. epidermidis to material. ${ }^{42}$ This may be attributed to a relatively high number of carboxyl groups, which generated a high concentration of acidic, negative charges and contributed to the reduction in S. epidermidis adhesion. However, another study indicated that the bacterial adhesion was increased when orthopedic implant polymers were exposed to hyaluronic acid before exposure to E. coli and $P$. aeruginosa. ${ }^{43}$ The nature of the functional groups on hyaluronan may have a greater effect on growing and colonization leading to a lower bacterial adhesion after $12 \mathrm{~h}$, while having less of an affect on the initial bacterial adhesion.
Nordmam and coworkers reported that polyvinyl chloride (PVC), silicone, and polyethylene (PE) with end-point attached heparin reduced S. epidermidis adhesion. ${ }^{28,29}$ Moreover, reduced E. coli attachment to the catheter surface was demonstrated for Latex, Teflon coated Latex and vinyl catheters with a heparin coating. ${ }^{44}$ Also, adhesion of $S$. epidermidis to intraocular lenses (IOL) made of heparin-surface-modified poly(methyl methacylate) (PMMA) was found to be lower than PMMA alone, in an in vitro study. ${ }^{45,46}$ However, in our study, the adhesion of $S$. epidermidis on heparin/OTS/silicone after 4 and $12 \mathrm{~h}$ incubation was found to be significantly higher. This result is in contrast with several previous findings of bacterial adhesion on heparin surfaces. On the other hand, our findings agree with the study of Garcia-Saenz et al. $^{47}$ Moreover, it was reported that heparinized PE without preadsorbed serum increased bacterial adhesion over uncoated PE. ${ }^{28}$ This increased adhesion may relate to the fact that heparin has an abundance of $\mathrm{SO}_{3}^{-}$group and is an adhesion recipient for some Staphylococcus species. ${ }^{48}$ However, different effects of heparin observed on bacterial adhesion may also be due to differences in the nature of bacterial strains, heparin coating methods, and experimental protocols. In addition, there are reports that heparin inhibited the adhesion of the protein on the shunt surface and thus reduced the risk of colonization. ${ }^{49}$ Immobilization of protein on silicone surface can reduce bacterial adhesion by $75 \% .^{50} \mathrm{~A}$ parallel study, using the same set of coated samples, also demonstrated the heparin/OTS/silicone surface pro- 
moted astrocyte and choroid plexus cell adhesion the most, while cell adhesion was inhibited on FAS/ silicone surface. ${ }^{51}$ Interestingly, a similar bacterial adhesion trend was also observed for $E$. coli on the same set of samples. ${ }^{52}$

There is still a debate on the importance of the effects of hydrophobicity on the surface on bacterial adhesion. Some authors reported that increasing hydrophobicity of polymeric biomaterials increased staphylococcal adhesion, ${ }^{7,28,39}$ while other work has found no significant correlation between hydrophobicity of a material and bacterial adhesion. ${ }^{53}$ In this study, bacterial adhesion on the hyaluronan/OTS/ silicone was found to be much less than on the heparin/OTS/silicone, even though both have almost same degree of hydrophilicity. On the other hand, bacterial adhesion was reduced on FAS/silicone, which is more hydrophobic than silicone. However, bacterial adhesion on OTS/silicone is less than silicone even though the silicone surface was more hydrophobic than the OTS-silicone surface. Therefore, there appears to be no direct correlation between hydrophobicity/hydrophilicity of a material and bacterial adhesion. As discussed earlier, however, the nature of surface function groups appears to play a significant role in determining bacterial adhesion and colonization.

Yet another factor in bacterial adhesion may be the surface roughness. The three modified silicone surfaces (FAS, OTS, and hyaluronan/OTS) are much smoother than silicone, and the degree of bacterial adhesion and colonization are indeed lower on these smooth surfaces. This suggests that the roughness of these samples may also be a factor for bacterial adhesion and colonization. Similar results have shown that rougher surfaces can lead to higher amounts of bacterial adhesion. $^{54}$

\section{CONCLUSION}

S. epidermidis adhesion and colonization on modified silicone surfaces were analyzed by SEM and colony counting. The following conclusions can be made:

1. FAS, OTS, heparin, and hyaluronan coatings on silicone were stable as determined by contact angle measurement and XPS.

2. After 4 and $8 \mathrm{~h}$ of incubation, S. epidermidis adhesion is in the order of heparin/OTS/silicone $>$ silicone $>$ hyaluronan/OTS/silicone > OTS/ silicone $>$ FAS/silicone.

3. Hydrophobicity of the surface did not appear be a determining factor on the overall bacterial adhesion. The nature of surface functional group and surface roughness have a significant influence on the initial adhesion and subsequent colonization processes.

These findings are helpful for devising novel strategies to reduce shunt infections.

We also thank Professors Gina Shreve, Guangzhao Mao, and Howard Matthew for the instruments usage.

\section{References}

1. Drake JM, Kestle J. Rationale and methodology of the multicenter pediatric cerebrospinal fluid shunt design trial. Childs Nerv Syst 1996;12:434-447.

2. Drake JM, Kestle JTR. Determining the best cerebrospinal fluid shunt valve design: The pediatric valve design trial. Neurosurgery 1998;43:1259-1260.

3. Patwardhan RV, Nanda A. Implanted ventricular shunts in the United States: The billion-dollar-a-year cost of hydrocephalus treatment. Neurosurgery 2005;56:139-144.

4. Drake JM, Kestle JR, Milner R, Cinalli G, Boop F, Piatt J. Jr, Haines S, Schiff SJ, Cochrane DD, Steinbok P, MacNeil N. Randomized trial of cerebrospinal fluid shunt valve design in pediatric hydrocephalus. Neurosurgery 1998;43(2):294303.

5. Naradzay JFX, Browne BJ, Rolnick MA, Doherty RJ. Cerebral ventricular shunts. J Emerg Med 1999;17:311-322.

6. Wang KW, Chang WN, Shih TY, Huang CR, Tsai NW, Chang CS, Chuang YC, Liliang PC, Su TM, Rau CS, Tsai YD, Cheng $\mathrm{BC}$, Hung PL, Chang CJ, Lu CH. Infection of cerebrospinal fluid shunts: Causative pathogens, clinical features, and outcomes. Jpn J Infect Dis 2004;57(2):44-48.

7. Cagavi F, Akalan N, Celik H, Gur D, Guciz B. Effect of hydrophilic coating on microorganism colonization in silicone tubing. Acta Neurochir 2004;146:603-610.

8. Richards H, Seeley H, Pickard J. Reasons for shunting and reasons for revision: A survey based on data from the UK Shunt Registry. Cerebrospinal Fluid Res 2004;1 (Suppl 1):S49.

9. Sri Paran T, Koenigs I, Fitzgerald R. VP shunts-What is the commonest complication? Cerebrospinal Fluid Res 2004;1 (Suppl 1):S25.

10. Bayston R, Ashraf W, Bhundia C. Mode of action of an antimicrobial biomaterial for use in hydrocephalus shunts. J Antimicrob Chemother 2004;53:778-782.

11. Ronan A, Hogg GG, Klug GL. Cerebrospinal-fluid shunt infections in children. Pediatr Infect Dis J 1995;14:782-786.

12. Turgut M, Alabaz D, Erbey F, Kocabas E, Erman T, Alhan E, Aksaray N. Cerebrospinal fluid shunt infections in children. Pediatr Neurosurg 2005;41:131-136.

13. Dabernat H, Bauriaud R, Guitard J, Rajon AM, Brun Y, Delmas C, Huguet JC. Bacteriologic and scanning electron-microscopic studies of cerebrospinal-fluid shunt infections. Nouvelle Revue De Medecine De Toulouse 1985;3:15-20.

14. Del Bigio MR. Biological reactions to cerebrospinal fluid shunt devices: A review of the cellular pathology. Neurosurgery 1998;42:319-325.

15. Reinprecht A, Dietrich W, Berger A, Bavinzski G, Weninger M, Czech T. Posthemorrhagic hydrocephalus in preterm infants: Long-term follow-up and shunt-related complications. Childs Nerv Syst 2001;17:663-669.

16. Prescott LM, Harley JP, Klein DA. Microbiology. New York: McGraw-Hill; 2004.

17. Elek S, Conon P. The virulence for Staphylococcus pyogenes for man: A study of the problems of wound infection. Br J Exp Pathol 1961;42:269-277. 
18. Bayston R. A model of catheter colonization in vitro and its relationship to clinical catheter infections. J Infect 1984;9:271276.

19. Borges L. Cerebrospinal fluid shunts interfere with host defenses. Neurosurgery 1982;10:55-59.

20. Kalousdian S, Karlan MS, Williams MA, Bresolin LB, Affairs CS, Assoc AM. Silicone elastomer cerebrospinal fluid shunt systems. Neurosurgery 1998;42:887-892.

21. Kohnen W, Kolbenschlag C, Teske-Keiser S, Jansen B. Development of a long-lasting ventricular catheter impregnated with a combination of antibiotics. Biomaterials 2003;24:48654869.

22. Arciola CR, Campoccia D, Montanaro L. Effects on antibiotic resistance of Staphylococcus epidermidis following adhesion to polymethylmethacrylate and to silicone surfaces. Biomaterials 2002;23:1495-1502.

23. Govender ST, Nathoo N, van Dellen JR. Evaluation of an antibiotic-impregnated shunt system for the treatment of hydrocephalus. J Neurosurg 2003;99:831-839.

24. Sciubba DM, Stuart M, McGirt MJ, Woodworth GF, Samdani A, Carson B, Jallo GI. Effect of antibiotic-impregnated shunt catheters in decreasing the incidence of shunt infection in the treatment of hydrocephalus. J Neurosurg 2005;103:131-136.

25. Aryan H, Meltzer H, Park M, Bennett R, Jandial R, Levy M. Initial experience with antibiotic-impregnated silicone catheters for shunting of cerebrospinal fluid in children. Childs Nerv Syst 2004;21:56-61.

26. Cicalini S, Palmieri F, Petrosillo N. Clinical review: New technologies for prevention of intravascular catheter-related infections. Crit Care 2004;8:157-162.

27. Liang XM, Wang AF, Cao T, Tang HY, McAllister JP, Salley $\mathrm{SO}$, Ng KYS. Effect of cast molded rifampicin/silicone on Staphylococcus epidermidis biofilm formation. J Biomed Mater Res A 2006;76:580-588.

28. Nomura S, Lundberg F, Stollenwerk M, Nakamura K, Ljungh A. Adhesion of staphylococci to polymers with and without immobilized heparin in cerebrospinal fluid. J Biomed Mater Res 1997;38:35-42.

29. Yu J, Montelius MN, Paulsson M, Gouda I, Larm O, Montelius L, Ljungh A. Adhesion of coagulase-negative Staphylococci and adsorption of plasma-proteins to heparinized polymer surfaces. Biomaterials 1994;15:805-814.

30. Chen GP, Ito Y, Imanishi Y, Magnani A, Lamponi S, Barbucci R. Photoimmobilization of sulfated hyaluronic acid for antithrombogenicity. Bioconjug Chem 1997;8:730-734.

31. Fang JY, Knobler CM. Phase-separated two-component selfassembled organosilane monolayers and their use in selective adsorption of a protein. Langmuir 1996;12:1368-1374.

32. ULF J, Goran O. Chemical vapour deposition of silanes. Thin Solid Films 1985;124:117-123.

33. Banga R, Yarwood J, Morgan AM, Evans B, Kells J. FTIR and AFM studies of the kinetics and self-assembly of alkyltrichlorosilanes and (perfluoroalkyl)trichlorosilanes onto glass and silicon. Langmuir 1995;11:4393-4399.

34. Sugimura H, Ushiyama K, Hozumi A, Takai O. Micropatterning of alkyl- and fluoroalkylsilane self-assembled monolayers using vacuum ultraviolet light. Langmuir 2000;16:885888.

35. Price C, Waters MGJ, Williams DW, Lewis MAO, Stickler D. Surface modification of an experimental silicone rubber aimed at reducing initial candidal adhesion. J Biomed Mater Res 2002;63:122-128.
36. Everaert EPJM, Mei HCvd, Busscher HJ. Adhesion of yeasts and bacteria to fluoro-alkylsiloxane layers chemical on silicone rubber. Colloids Surf B 1998;10:179-190.

37. An YH, Friedman RJ. Concise review of mechanisms of bacterial adhesion to biomaterial surfaces. J Biomed Mater Res 1998;43:338-348.

38. Paulsson M, Kober M, Freijlarsson C, Stollenwerk M, Wesslen B, Ljungh A. Adhesion of Staphylococci to chemically-modified and native polymers, and the influence of preadsorbed fibronectin, vitronectin and fibrinogen. Biomaterials 1993;14:845-855.

39. Ludwicka A, Jansen B, Wadstrom T, Pulverer G. Attachment of Staphylococci to various synthetic-polymers. Zentralbl Bakteriol Mikrobiol Hyg [A] 1984;256:479-489.

40. Wang AF, Cao T, Tang HY, Liang XM, Salley SO, Ng KYS. In vitro haemocompatibility and stability of two types of heparin-immobilized silicon surfaces. Colloids Surf B 2005;43(3/4): 245-255.

41. Madigan MT, Martinko JM, Parker J. Brock Biology of Microorganisms. New Jersey: Prentice-Hall, Inc.; 1997, p 717-719.

42. Magnani A, Barbucci R, Montanaro L, Arciola CR, Lamponi $\mathrm{S}$. In vitro study of blood-contacting properties and effect on bacterial adhesion of a polymeric surface with immobilized heparin and sulphated hyaluronic acid. J Biomater Sci Polym Ed 2000;11:801-815.

43. Barton AJ, Sagers RD, Pitt WG. Bacterial adhesion to orthopedic implant polymers. J Biomed Mater Res 1996;30:403-410.

44. Ruggieri M, Hanno P, Levin R. Reduction of bacterial adhesion to catheter surface with heparin. J Urol 1987;138:423-426.

45. Portoles M, Refojo MF, Leong FL. Reduced bacterial adhesion to heparin-surface-modified intraocular lenses. J Cataract Refract Surg 1993;19:755-759.

46. Arciola C, Caramazza R, Pizzoferrato A. In-vitro adhesion of Staphylococcus epidermidis on heparin-surface-modified intraocular lenses. J Cataract Refract Surg 1994;3:195-202.

47. Garcia-Saenz MC, Arias-Puente A, Fresnadillo-Martines MJ, Matilla-Rodriguez A. In vitro adhesion of Staphylococcus epidermidis to intraocular lenses. J Cataract Refract Surg 2000;26: 1673-1679.

48. Rostand K, Esko J. Microbial adherence to and invasion through proteoglycans. Infect Immun 1997;65:1-8

49. Lundberg F, Gouda I, Larm O, Galin MA, Ljungh A. A new model to assess staphylococcal adhesion to intraocular lenses under in vitro flow conditions. Biomaterials 1998;19:1727-1733.

50. Tang HY, Wang AF, Cao T, Liang XM, Salley SO, McAllister JP, Ng KYS. Effect of surface proteins on Staphylococcus epidermidis adhesion and colonization on silicone. Colloids Surf B 2006:51:16-24.

51. Patel KR, Tang HY, Grever WE, Ng KYS, Xiang JM, Keep RF, Cao T, McAllister JP. Evaluation of polymer and selfassembled monolayer-coated silicone surfaces to reduce neural cell growth. Biomaterials 2006;27:1519-1526.

52. Cao T, Tang HY, Liang XM, Wang AF, Auner GW, Salley SO, $\mathrm{Ng}$ KYS. Nanoscale investigation on adhesion of bacteria to surface modified silicone rubber using atomic force microscopy. Biotechnol Bioeng 2006;94:167-176.

53. Baveja JK, Willcox MDP, Hume EBH, Kumar N, Odell R, Poole-Warren L. Furanones as potential anti-bacterial coatings on biomaterials. Biomaterials 2004;25:5003-5012.

54. Reid G, Hawthorn LA, Eisen A, Beg HS. Adhesion of Lactobacillus acidophilus, Escherichia coli and Staphylococcus epidermidis to polymer and urinary catheter surfaces. Colloids Surf 1989; 42(3/4):299-311. 